\section{Efficacy of Denture Cleansers in Reducing Microbial Counts from Removable Partial Dentures: A Short-Term Clinical Evaluation}

Silvia Carneiro de Lucena-Ferreira, Indira Moraes Gomes Cavalcanti, Altair Antoninha Del Bel Cury
Department of Prosthodontics and Periodontology, Piracicaba School of Dentistry, UNICAMP - University of Campinas, Piracicaba, SP, Brazil

Correspondence: Profa. Dra. Altair Antoninha Del Bel Cury, Avenida Limeira 901, 13414-903 Piracicaba, SP, Brasil. Tel: +55-19-21065294. Fax: +55-19-2106-5250. e-mail: altcury@fop.unicamp.br

\begin{abstract}
This clinical study investigated if daily immersion in denture cleansers reduces microbial counts on removable partial denture's (RPD) biofilm. Twenty-five RPD wearer volunteers were selected and instructed to complement the hygiene of their dentures by immersing them in an enzymatic peroxide-based denture cleanser (Polident ${ }^{\circledast} 3$ minute) once a day for $3 \mathrm{~min}$ for a period of 15 days. The biofilm was collected from RPD surfaces with a swab immediately before (baseline) and after the experimental period. The samples were placed in sterile saline solution, sonicated at $7 \mathrm{~W}$ and then plated on specific culture media to quantify total microorganisms, total streptococci and Candida spp. counts. Data from both collections were compared by paired t-test $(\alpha=0.05)$. It was observed a significant reduction on total microorganisms' counts in RPD biofilm after denture cleanser use $(p=0.007)$. This reduction was also observed for total streptococci $(p=0.0428)$, but no difference was observed on Candida spp. counts. It was concluded that daily use of denture cleanser improved denture hygiene by reducing total microorganisms and total streptococci from RPD surface but had no effect on Candida spp. population.
\end{abstract}

Key Words: removable partial denture, biofilms, denture cleansers.

\section{Introduction}

Poor oral hygiene and consequent biofilm accumulation on removable partial dentures (RPD) can increase the incidence of tissue inflammation and caries on abutment teeth (1). In addition to local diseases, biofilm is a well recognized reservoir of microorganisms that can also cause important systemic infections (2). Therefore, the establishment of an adequate oral hygiene is of great importance for oral and systemic health and should contemplate an adequate control of biofilm on RPD surfaces.

Brushing is a simple and widely used method to clean removable dentures $(3,4)$. However, the frequent visual and manual limitations presented by some patients (5), combined with the difficulties imposed by RPD design, can impair complete biofilm removal by brushing. Thus, the use of chemical solutions has been recommended as complementary method for dentures hygiene (6). Denture cleansers are commercially available solutions efficient in controlling biofilms $(7,8)$ and, when introduced in patients' oral hygiene routine, they are able to improve biofilm control as observed in clinical studies with complete denture wearers $(6,9,10)$.

Regarding partial dentures, although some in vitro studies have investigated the use of denture cleansers for RPD hygiene, the main focus has been on investigating the possible harmful effects on prosthesis components, especially metallic framework (11-13). For biofilm control, while many studies evaluated complete dentures and found favorable results, little is known about its effectiveness in controlling biofilm in RPD. Thus, the aim of this clinical study was to evaluate if RPD daily immersion in a denture cleansing solution in combination with the routine method of cleansing could reduce microbial counts on biofilm.

\section{Material and Methods}

The study population consisted of patients that were rehabilitated with RPD at the University Dental Clinic. Subjects were eligible to participate if they presented good oral and systemic health conditions, did not use any antimicrobial in the last 3 months, had ability to comply with the experimental protocol, were continuously using the RPD and used brushing as the only method for denture hygiene. The selected volunteers signed the informed consent and were submitted to anamnesis, clinical examination and the first denture biofilm collection was performed (baseline).

The volunteers were instructed to brush their RPD as usual complementing hygiene by immersing their dentures in an enzymatic peroxide-based denture cleanser presented in tablets (Polident ${ }^{\oplus} 3$ Minute; GlaxoSmithKline, Philadelphia, PA, USA) once a day for $3 \mathrm{~min}$, after the nocturnal brushing. The cleansing solution was prepared by dissolving one tablet of denture cleanser in $200 \mathrm{~mL}$ of warm tap water. Dentures should be rinsed in running 
water before reinsertion into the oral cavity. The volunteers were asked to keep on brushing their dentures as usual, and no additional hygiene instructions were provided to avoid any bias. After 15 days, the volunteers returned for the post-treatment biofilm collection.

For both baseline and post-treatment biofilm collections, RPDs were removed, gently washed with sterile distilled water to remove debris and saliva and then a sterile swab was rubbed onto the whole denture inner and outer surfaces always in the same way - first clasps followed by teeth and acrylic resin base. The swab was immediately placed in a polypropylene tube containing $3 \mathrm{~mL}$ of sterile saline solution ( $\mathrm{NaCl} 0.9 \%$ ) and then sonicated at $7 \mathrm{~W}$ for 30 s. The resulting suspension containing biofilm was 10 -fold diluted and inoculated in triplicate by the drop-counting technique in the following culture media: Columbia Blood Agar (Difco BD, Franklin Lakes, NJ, USA) supplemented with 5\% (v/v) defibrinated sheep blood, Mitis Salivarius Agar (MSA; Difco BD) and CHROMagar ${ }^{\mathrm{TM}}$ Candida (Difco BD) for total microorganisms, total streptococci and Candida spp., respectively. The plates were incubated for $48 \mathrm{~h}$ at $37^{\circ} \mathrm{C}$ in aerobiosis (CHROMagar ${ }^{\mathrm{TM}}$ Candida) and 10\% carbon dioxide (blood agar and MSA) and the number of colony-forming units (CFU) was quantified using a stereomicroscope (Coleman ST30-2L; Coleman Equipamentos, Santo André, $\mathrm{SP}$, Brazil) in the dilutions containing between 6 and $60 \mathrm{CFU}$.

The data from both collections were compared by paired t-test with a significance level fixed at 5\% (SAS v. 9.0; SAS Institute, Inc., Cary, NC, USA).

\section{Results}

The final sample consisted of 25 volunteers ( 12 male, mean age: $57 \pm 8.6$ years) (Fig. 1). From the RPD analyzed, 12 were located in the maxillary arch and the mean period of RPD usage was 8.4 months. It was observed a significant reduction of total microorganisms' counts in RPD biofilms after denture cleanser use ( $p=0.007$; Table 1$)$. Total streptococci also had a significant decrease ( $p=0.0428$; Table 1) in accordance with total microorganism results. In the present sample, 11 volunteers had Candida spp. at baseline

Table 1. Microbial count on removal partial denture biofilm at baseline and post-treatment biofilm collections (mean $\pm s d ; n=25$ )

\begin{tabular}{lccc}
\hline $\begin{array}{l}\text { Biofilm } \\
\text { collection }\end{array}$ & $\begin{array}{c}\text { Total } \\
\text { microorganisms } \\
\left(\times 10^{8}\right)\end{array}$ & $\begin{array}{c}\text { Total } \\
\text { Streptococci } \\
\left(\times 10^{7}\right)\end{array}$ & $\begin{array}{c}\text { Candida } \\
\text { spp. } \\
\left(\times 10^{4}\right)\end{array}$ \\
\hline Baseline & $2.2 \pm 2.4^{\mathrm{a}}$ & $7.3 \pm 8.9^{\mathrm{a}}$ & $6.6 \pm 12.8^{\mathrm{a}}$ \\
Post-treatment & $0.8 \pm 1.1^{\mathrm{b}}$ & $4.7 \pm 6.8^{\mathrm{b}}$ & $9.3 \pm 18.2^{\mathrm{a}}$ \\
\hline
\end{tabular}

Different letters indicate statistically significant difference between baseline and post-treatment data. collection and no difference was observed on Candida spp. counts after denture cleanser use ( $p>0.005$; Table 1$)$.

\section{Discussion}

The findings of the present study showed that the daily use of a denture cleanser was effective on reducing total microorganisms' counts on RPD surface. This finding is in agreement with those of previous studies, which have reported effectiveness of peroxide-effervescent denture cleansers in reducing microbial population on dentures surface $(14,15)$. This effectiveness of alkaline-peroxides denture cleansers in biofilm control has been attributed to the mechanical action exerted by the effervescence produced when the product is dissolved in water; additionally, the resulting solution presents hydrogen peroxide and active oxygen, which have antimicrobial effects, and enzymes that break down proteins in biofilm (16). On the other and, Oliveira et al. (17) have found different results in a clinical study and reported no reduction of total microorganisms after daily use of peroxide-effervescent denture cleanser. This divergence can be explained by differences in the methodological aspects, such as the investigation of patients from a long-term institution who may not have brushed properly during experimental period.

The present study also evaluated the effect of denture cleanser on total streptococci for being one of the most prevalent bacteria isolated from removable dentures biofilm; also, this genus includes some clinically relevant species related to oral or systemic diseases such as Streptococcus mutans and S. pneumonie $(2,18)$. The daily use of denture cleanser was able to reduce total streptococci

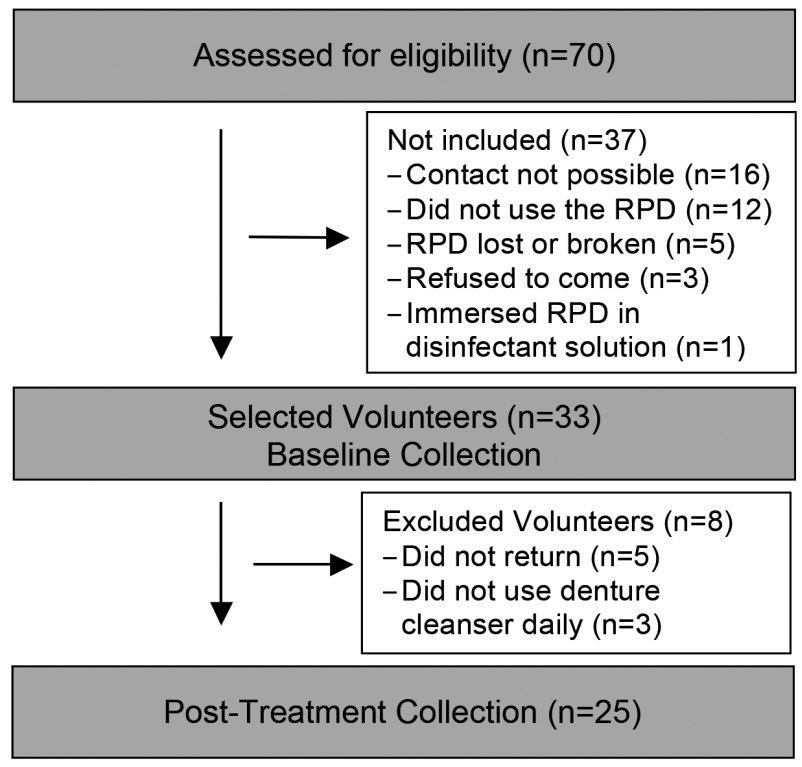

Figure 1. Flowchart of the selection of volunteers (DC: denture cleanser). 
population on RPD biofilm, following total microorganisms reduction. In contrast to these results, in the present study, denture cleanser had no effect on Candida spp. population. Actually, some individuals had an increase in Candida spp. counts after denture cleanser use, which is an important finding considering that some species, mainly $C$. albicans, are associated with the development of denture-related stomatitis (19).

The lack of effect of denture cleanser on Candida spp. goes against some results from in vitro studies that have found a significant action of this product against these microorganisms. However, it must be pointed that these studies used pure fungal biofilms $(7,20,21)$. When confronting the results of the present study with those of in vitro and in vivo studies evaluating mixed bacterial-fungal biofilms $(14,15,22)$, the outcomes are similar. Andrade et al. (15) assessed clinically the effect of different denture cleansing protocols and found that, after 21 days of denture cleanser use, there was a significant reduction of $S$. mutans but no reduction was observed for $C$. albicans population.

In order to explain the different response of streptococci and candida species when a mixed biofilm is exposed to denture cleanser, it has been hypothesized that streptococci may be located in more superficial layers of the biofilm and consequently are more exposed to antimicrobial agents. In addition, S. mutans produces a barrier of glucan that could limit the exposure of yeast cells to cleansing solution. Thus, in a multispecies biofilm, Candida spp. would be protected from denture cleanser action by layers of extracellular matrix and bacterial cells $(15,22)$.

Some limitations of the present study should be pointed as the absence of a control group and the shortterm evaluation. Future studies should be conducted for longer periods to investigate whether this stronger effect of denture cleanser on bacterial cells could lead to a selection of Candida spp. and if this finding could have any clinical relevance, especially to some groups of patients, like the immunocompromised individuals.

From the obtained results, it was concluded that the daily use of denture cleanser should be recommended to limit the exposure of patients to potentially pathogenic microorganisms as it reduced the counts of total microorganisms and total streptococci on RPD. However, no effect was observed on Candida spp. counts, a finding that deserves future investigations.

\section{Resumo}

Este estudo clínico investigou se a imersão diária de próteses parciais removiveis (PPR) em limpador químico reduz as contagens de microorganismos no biofilme. Vinte e cinco voluntários que utilizavam PPR foram selecionados e instruidos a complementar a higiene das PPRs imergindo suas próteses em um limpador químico enzimático (Polident ${ }^{\oplus}$ 3 minute) uma vez por dia, por $3 \mathrm{~min}$, durante 15 dias. 0 biofilme foi coletado da superficie das próteses com auxílio de um swab imediatamente antes (baseline) e após o periodo experimental. A amostra foi imersa em solução salina estéril, submetida a sonicação a 7 W, e semeada em meios de cultura específicos para quantificar micro-organismos totais, estreptococos totais e Candida spp. Os dados de ambas as coletas foram comparados pelo teste t pareado $(\alpha=0,05)$. Foi observada uma redução significativa nas contagens de micro-organismos totais no biofilme da PPR após o uso do limpador químico $(p=0,007)$. Essa redução também foi observada para estreptococos totais $(p=0,0428)$, mas não foi observada diferença nas contagens de Candida spp. Concluiu-se que o uso diário do limpador químico melhorou a higienização das próteses por reduzir o número de micro-organismos totais e estreptococos totais na superficie da PPR, mas não teve efeito sobre a população de Candida spp.

\section{Acknowledgements}

This study was supported by Brazilian National Agency for Science and Technology (grant \#2006-7/308141). The authors thank FAPEMA (BD 00296/10) for the PhD scholarship for the first author.

\section{References}

1. Preshaw PM, Walls AWG, Jakubovics NS, Moynihan PJ, Jepson NJA Loewy Z. Association of removable partial denture use with oral and systemic health. J Dent 2011;39:711-719.

2. Glass RT, Conrad RS, Bullard JW, Goodson LB, Mehta N, Lech SJ, et al. Evaluation of microbial flora found in previously worn prostheses from the Northeast and Southwest regions of the United States. J Prosthet Dent 2010;103:384-389.

3. Dikbas I, Koksal T, Calikkocaoglu S. Investigation of the cleanliness of dentures in a university hospital. Int J Prosthodont 2006;19:294-298.

4. Peracini A, Andrade IM, Paranhos Hde F, Silva $\mathrm{CH}$, de Souza RF Behaviors and hygiene habits of complete denture wearers. Braz Dent J 2010;21:247-252.

5. Padilha DM, Hugo FN, Hilgert JB, Dal Moro RG. Hand function and oral hygiene in older institutionalized Brazilians. J Am Geriatr Soc 2007; 55:1333-1338.

6. Nishi Y, Seto K, Kamashita Y, Take C, Kurono A, Nagaoka E. Examination of denture-cleaning methods based on the quantity of microorganisms adhering to a denture. Gerodontology 2012; 29:259-566.

7. de Freitas Fernandes FS, Pereira-Cenci T, da Silva WJ, Filho AP, Straioto FG, Del Bel Cury AA. Efficacy of denture cleansers on Candida spp. biofilm formed on polyamide and polymethyl methacrylate resins. J Prosthet Dent 2011;105:51-58.

8. Pellizzaro D, Polyzois G, Machado AL, Giampaolo ET, Sanitá PV, Vergani CE. Effectiveness of mechanical brushing with different denture cleansing agents in reducing in vitro Candida albicans biofilm viability. Braz Dent J 2012;23:547-554.

9. Paranhos HF, Silva-Lovato $C H$, Souza RF, Cruz PC, Freitas KM, Peracini A. Effects of mechanical and chemical methods on denture biofilm accumulation. J Oral Rehabil 2007;34:606-612.

10. Cruz PC, Andrade IM, Peracini A, Souza-Gugelmin MC, Silva-Lovato CH, de Souza RF, et al.. The effectiveness of chemical denture cleansers and ultrasonic device in biofilm removal from complete dentures. J Appl Oral Sci 2011;19:668-673.

11. Felipucci DN, Davi LR, Paranhos HF, Bezzon OL, Silva RF, Barbosa Junior $F$, et al.. Effect of different cleansers on the weight and ion release of removable partial denture: an in vitro study. J Appl Oral Sci 2011;19:483-487.

12. Felipucci DN, Davi LR, Paranhos HF, Bezzon OL, Silva RF, Pagnano VO. Effect of different cleansers on the surface of removable partial denture. Braz Dent J 2011;22:392-397.

13. Davi LR, Felipucci DN, de Souza RF, Bezzon OL, Lovato-Silva $\mathrm{CH}_{\text {, }}$ Pagnano VO, et al.. Effect of denture cleansers on metal ion release and surface roughness of denture base materials. Braz Dent J 2012;23:387393.

14. Dills SS, Olshan AM, Goldner S, Brogdon C. Comparison of the antimicrobial capability of an abrasive paste and chemical-soak 
denture cleaners. J Prosthet Dent 1988:60:467-470.

15. de Andrade IM, Cruz PC, da Silva CHL, de Souza RF, Paranhos HFO, Candido RC et al. Effervescent tablets and ultrasonic devices against Candida and mutans streptococci in denture biofilm. Gerodontology 2011;28:264-270.

16. Budtz-Jorgensen E. Materials and methods for cleaning dentures. J Prosthet Dent 1979;42:619-623.

17. de Oliveira VM, de Lucena SC, Garcia RC, Del Bel Cury AA. Effect of a denture cleanser on the concentration of volatile sulphur compounds and denture biofilm in institutionalised elderly. Gerodontology 2011;28:134-139.

18. Kulak Y, Arikan A, Kazazoglu E. Existence of Candida albicans and microorganisms in denture stomatitis patients. J Oral Rehabil 1997;24:788-790.

19. Figueiral MH, Azul A, Pinto E, Fonseca PA, Branco FM, Scully C. Denture- related stomatitis: identification of aetiological and predisposing factors - a large cohort. J Oral Rehabil 2007;34:448-455.

20. Nikawa H, Yamamoto T, Hamada T, Sadamori S, Agrawal S. Cleansing efficacy of commercial denture cleansers: ability to reduce Candida albicans biofilm activity. Int J Prosthodont 1995;8:527-534.

21. Jose A, Coco BJ, Milligan S, Young B, Lappin DF, Bagg J, Murray $C$, Ramage $G$. Reducing the incidence of denture stomatitis: are denture cleansers sufficient? J Prosthodont 2010;19:252-257.

22. Drake D, Wells J, Ettinger R. Efficacy of denture cleansing agents in an in vitro bacteria-yeast colonization model. Int J Prosthodont 1992;5:214-220.

Received February 14, 2013 Accepted July 25, 2013 